\title{
Interactive technologies for forming professional competences of management and pedagogical teams in an inclusive organization
}

\author{
Viktoriia Manuilova $^{1 *}$, Acsha Guseynova ${ }^{1}$, and Vera Khitryuk $^{1}$ \\ ${ }^{1}$ Moscow City University, Institute of Special Education and Psychology, Department of Speech \\ Therapy, Moscow, Russia
}

\begin{abstract}
This work is devoted to one of the key problems of existing Russian education: creating conditions for access to education for children with limited health capacities (LHC) and disabilities. The authors analyze in details the issues of determination and development of special (personnel, program and methodical, material and technical, organizational) conditions in educational entities of various levels of learning. The monitoring results of readiness of managerial and pedagogical teams of schools and colleges for inclusive education are presented. The monitoring was performed in schools of Moscow and vocational educational entities (colleges) implementing the programs of training qualified workers, officers, and experts of middle level in ten subjects of the Russian Federation. The following methods were applied during the monitoring: questionaries, surveys for heads of educational entities, subject teachers, supporting specialists, teachers, foremen of vocational training and parents of trainees with LHC and disabilities. According to the monitoring results, the conclusions have been made and key problems have been determined regarding provision of the educational entities with specialists skilled in professional competences in the field of inclusive education. In addition, staff deficits have been revealed in each educational entity and trends of development have been described regarding development of managerial and pedagogical teams concerning organization and implementation of inclusive education.
\end{abstract}

Keywords: staff resources, children with developmental disorders, schools, professional training entities

\section{Introduction}

The changes occurring in the existing education system in Russia evidence the necessity to review the requirements to professional competence of managerial and pedagogical teams of educational entities [1]. These changes are stipulated by implementation of inclusive trends at all stages of Russian education [2].

The inclusive education means inclusion of persons with disabilities and impaired development into general education process carried out in educational entities [3].

*Corresponding author: manuilovavv@mgpu.ru 
Inclusion of children with peculiar educational demands into the environment of normally developing children requires for creation of special conditions in educational entities, namely: provision of environment availability of educational entity (access ways, auditorial reserve, sanitary areas, etc.), as well as methodological, material and technical, personnel provision [4-5]. In the frames of this article, one group of special conditions will be considered: personnel provision [6-7].

While discussing the personnel provision, using which the educational entities perform inclusive education, it is required to estimate formation of general and professional competences of members both of managerial teams and of pedagogical staff.

Existence of supporting team (defectology teachers, speech therapists, psychologists, social workers) in an educational entity allows to only partially satisfy demands of all trainees and pupils [8-9]. Therefore, the importance of formation of inclusive competence for all workers of educational entity is obvious, this would allow providing staff conditions required for inclusion of disabled children into common educational environment [10].

\section{Methods}

With this aim the authors developed the profile of competences for a teacher in the sphere of inclusive education. A questionary on its basis was developed presented in the form of list of questions to managerial and pedagogical teams of educational entities with the answer ranking scale. The questions were subdivided into blocks, each block was comprised of questions grouped according to labor functions/professional competences.

Block 1. Organization and performance of studies by disciplines with disabled pupils;

Block 2. Extracurricular activities with disabled pupils on school subjects, courses, disciplines;

Block 3. Development, updating, and correction of school subject programs (their adaptation for capabilities of disabled pupils);

Block 4. Development and correction of methodological provision of school subjects (their adaptation for capabilities of disabled pupils);

Block 5. Implementation of training and/or professional practice with disabled pupils (for managerial and pedagogical teams of vocational educational entities);

Block 6. Support for self-identification of disabled pupils (personal and vocational);

Block 7. Informing and consulting disabled pupils and their parents during vocational oriented actions;

Block 8. Application of special technologies and methods allowing to perform special education;

Block 9. Development of personalized educational routes of disabled pupils.

The members of managerial and pedagogical teams of comprehensive schools and colleges of subjects of the Russian Federation were surveyed [11].

\section{Results}

Ten professional educational entities (Novokuznetsk, Kursk, Kurgan, Ryazan, Yaroslavl, Cherepovets, Kostroma, Tomsk, Gorno-Altaisk, Biysk) and five general educational entities (Moscow) participated in the research.

Total number of respondents was 150 persons: 10 persons from each educational entity of subjects of the Russian Federation participated in this research.

The obtained monitoring results were analyzed and generalized by each block of labor functions/professional competences. 
Let us consider them sequentially by the highlighted blocks. The first block estimated the competence related with classes by disciplines with disabled pupils. It can be seen in Figure 1 that an insignificant number of respondents who participated in the monitoring were skilled in this competence. This skill was the best mastered by teachers ( 7 persons) and heads and masters of professional educational entities (by 5 persons). The foremen of vocational training and the kindergarten teachers did not master this labor function. The lack in formation of this competence for members of managerial teams should be mentioned, while creation of inclusive environment in educational entity depends on these persons.

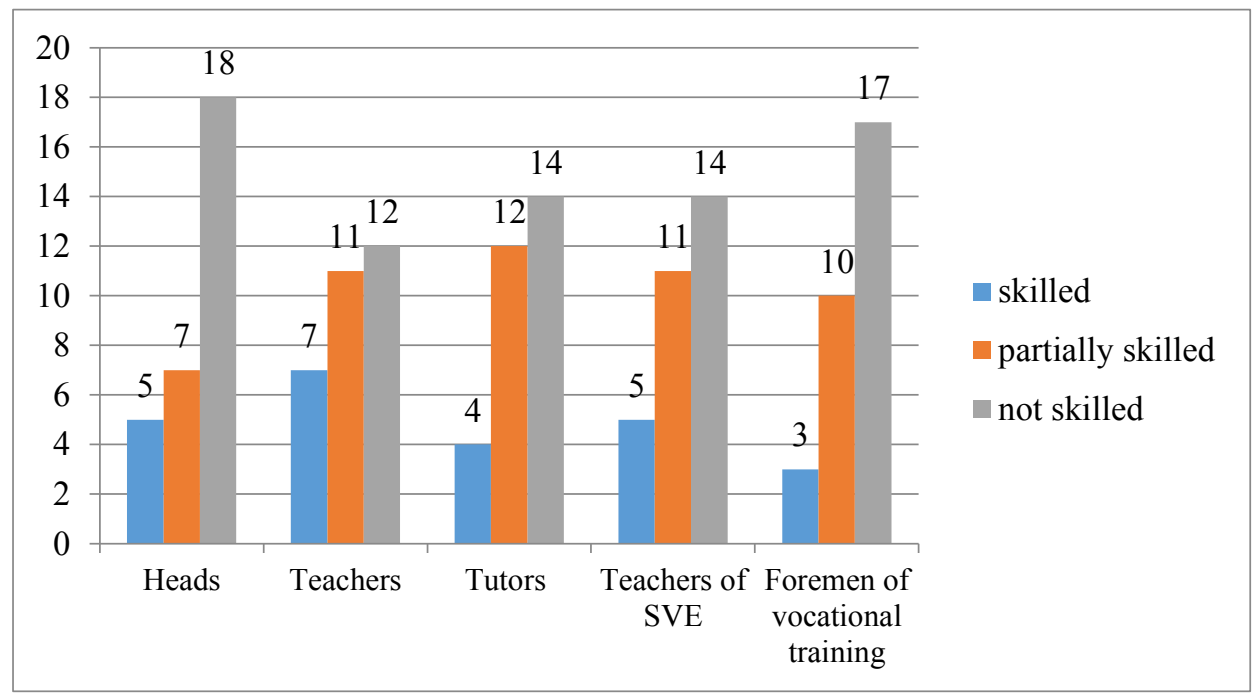

Fig. 1. Diagnostics for Block 1: Organization and implementation of classes by disciplines with disabled pupils.

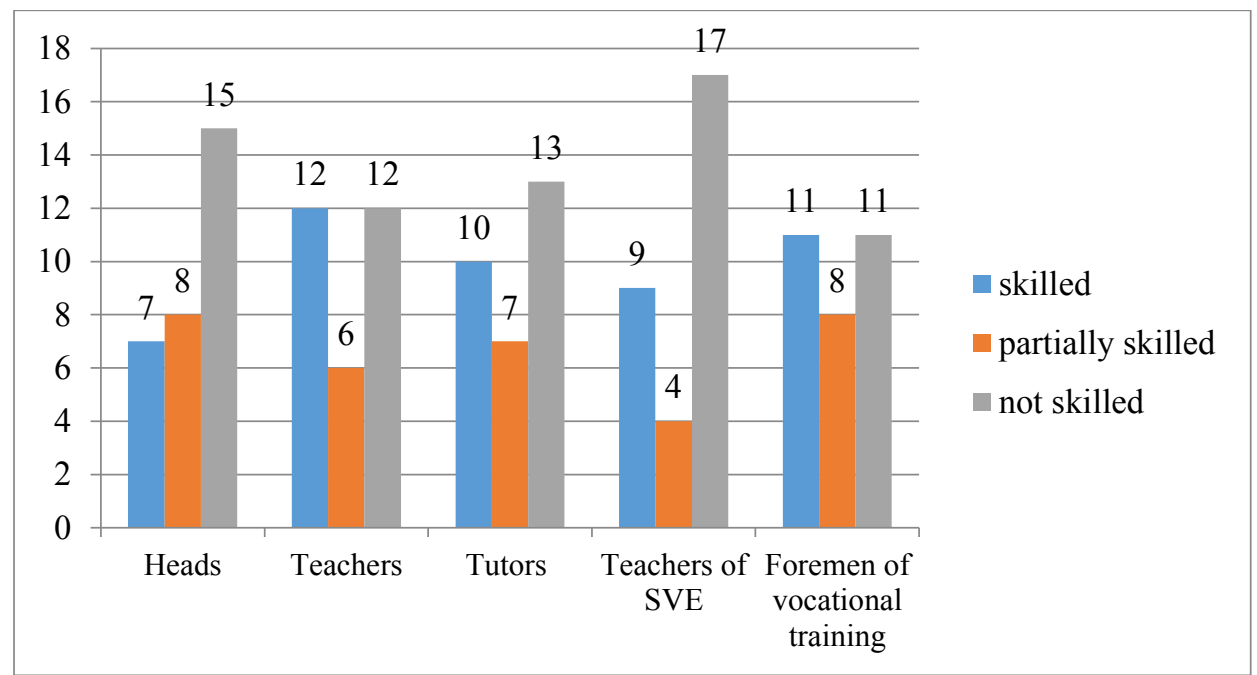

Fig. 2. Diagnostics for Block 2: Extracurricular activities with disabled pupils devoted to school subjects, courses, disciplines.

The results in Figure 2 allow to estimate formation of competence in the field of organization of independent work of disabled pupils. Among the teachers and foremen of vocational education, there are equal amount of participants giving "skilled" and "not skilled" 
responses, which evidences heterogeneous content of members even in one professional group. Thus, it can be concluded that the basic education in these professions does not provide for formation of inclusive professional competences.

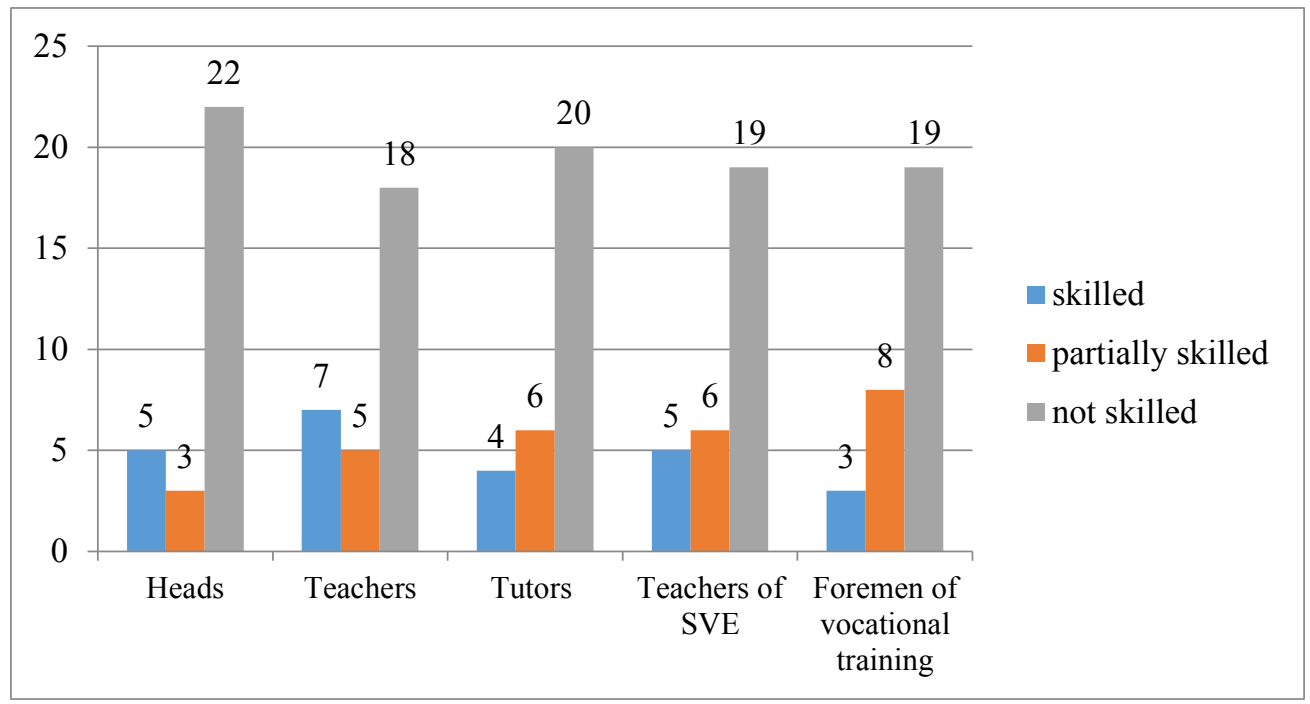

Fig. 3. Diagnostics for Block 3: Development, updating, and correction of school subject programs (their adaptation for capabilities of disabled pupils).

The indicator illustrated in Figures 3 and 4 is characterized by minimum data of "skilled" and "partially skilled" responses, which is expectable, since adaptation of school material and methodological provision requires for special (defectological) knowledge by respondents.

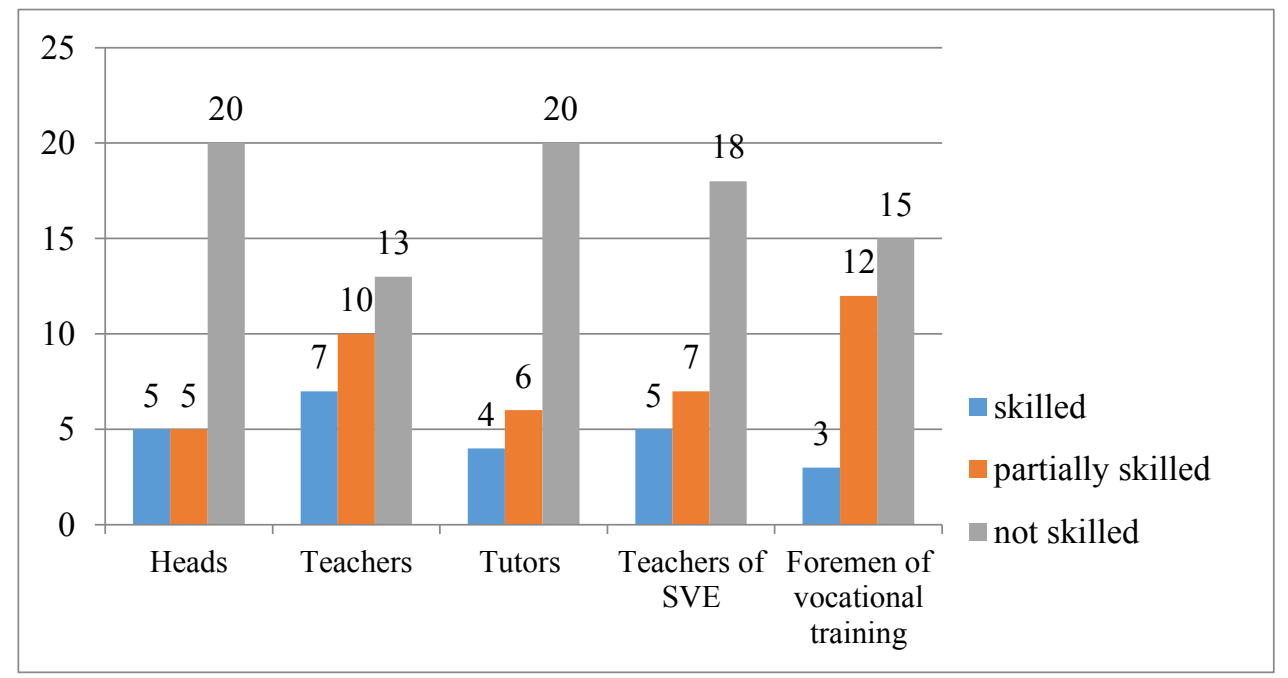

Fig. 4. Diagnostics for Block 4: Development and correction of methodological provision of school subjects (their adaptation for capabilities of disabled pupils). 


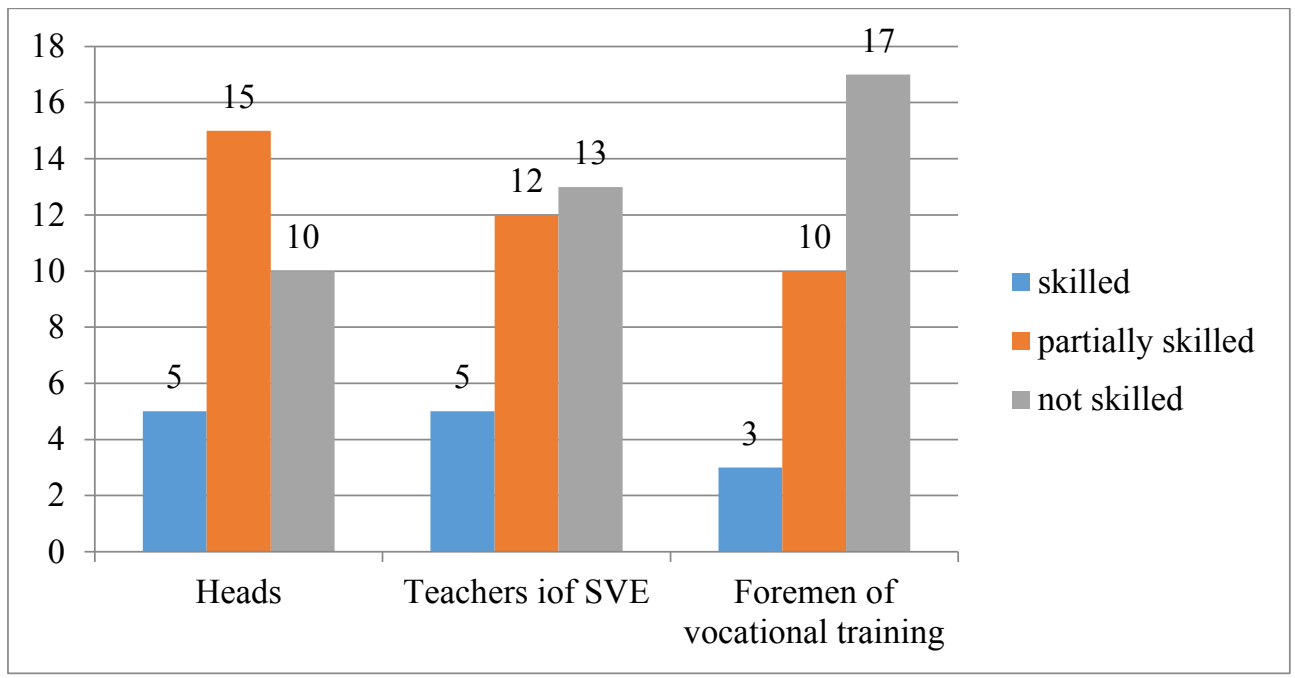

Fig. 5. Diagnostics for Block 5: Implementation of training and/or professional practice with disabled pupils (for managerial and pedagogical teams of vocational educational entities).

The results in Figure 5 show that most members of managerial teams possess organizational competence, which is expectable.

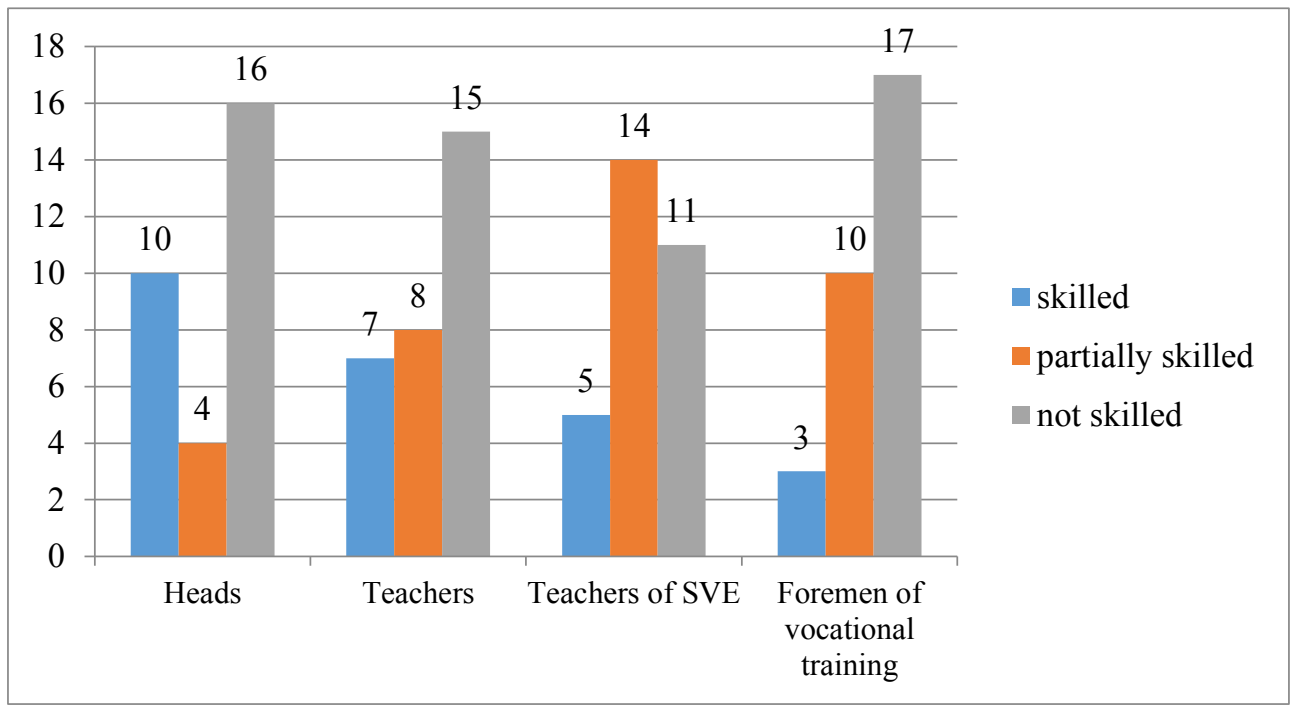

Fig. 6. Diagnostics for Block 6: Support for self-identification of disabled pupils (personal and vocational).

This indicator of professional competence is especially important, especially in the context of teaching disabled pupils. This competence allows to provide inclusion of disabled pupils into social environment, which is the main result of their education. 


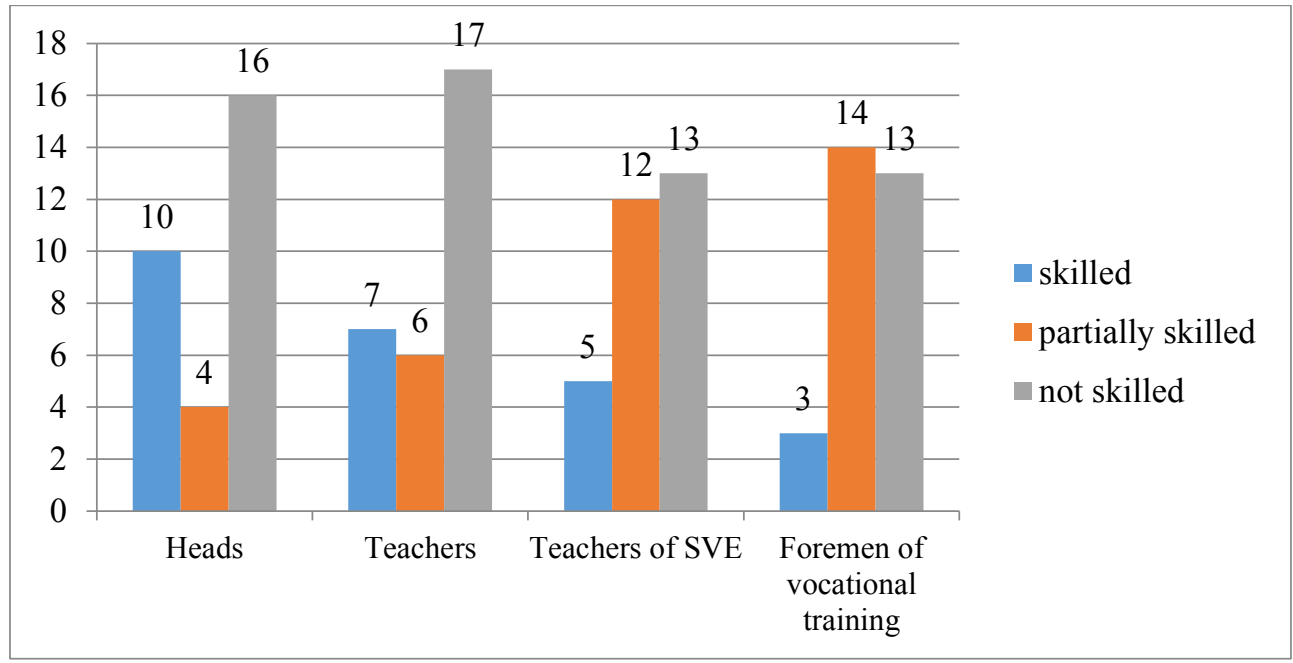

Fig. 7. Diagnostics for Block 7: Informing and consulting disabled pupils and their parents during vocational oriented actions.

Inclusion of parents of disabled pupils into learning process by members of managerial and pedagogical teams allows to provide integrity of requirements and approaches to education, which would be obviously positive in correction pedagogical work [12]. It is illustrated in Figure 7 that this competence is formed or partially formed for the following respondents: Teachers of SVE, Foremen of vocational training.

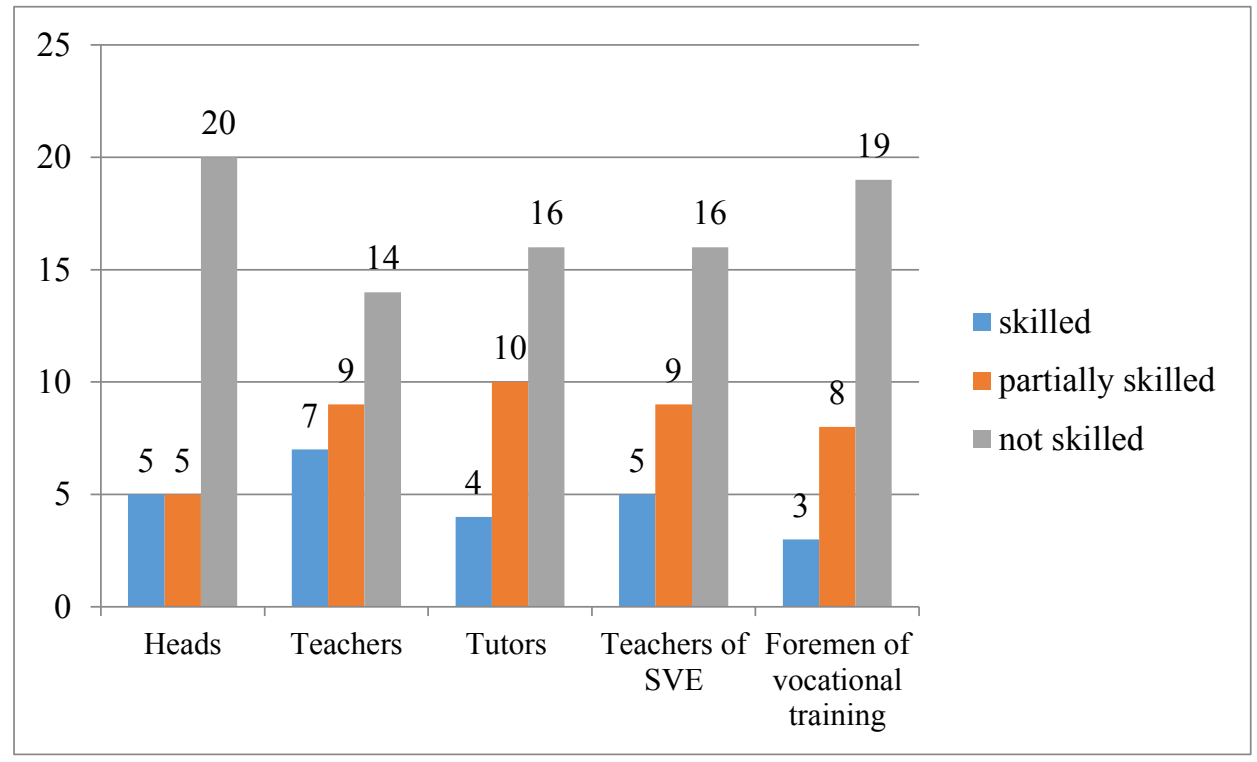

Fig. 8. Diagnostics for Block 8: Application of special technologies and methods allowing to perform special education.

Analysis of results for indicators 8 and 9 allows to reveal dominating lack of respondents' knowledge of special techniques and methods allowing to perform corrective pedagogical work (from 14 to 20 members in each vocational group), which prevents efficient construction of individual educational routes for disabled pupils. 


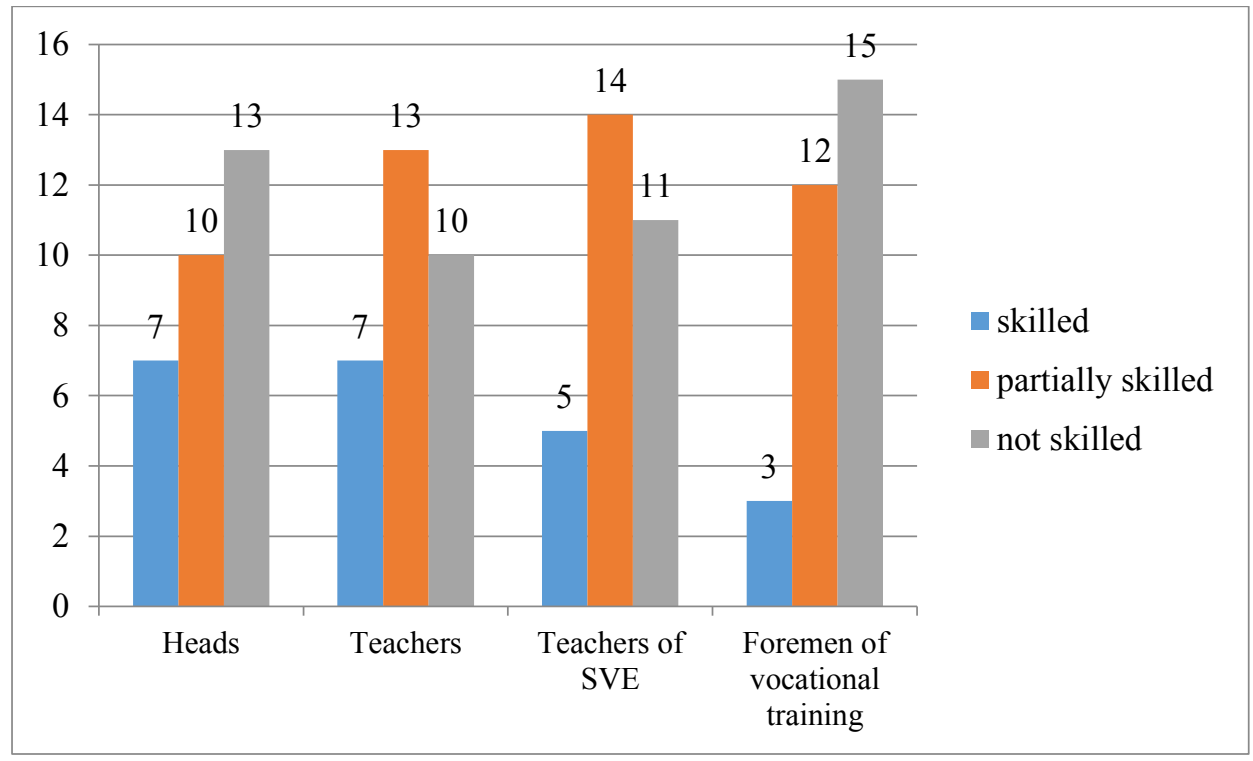

Fig. 9. Diagnostics for Block 9: Development of personalized educational routes of disabled pupils.

Therefore, the obtained monitoring results allowed to reveal bottlenecks in professional competences of managerial and pedagogical teams, to highlight the resulted risks and to determine possibilities to eliminate unpreparedness of personnel of educational entities for inclusive education.

\section{Discussion}

The monitoring results evidence that it is insufficient for managerial and pedagogical personnel of schools and colleges to complete the advanced training courses devoted to inclusive education in conventional lecture format. It is obvious that organization and implementation of preparedness of pedagogical officers to work in modern educational environment should be revised [13]. We believe that the most efficient formats of improvement of professional competence are interactive, practice oriented, searching forms of training of pedagogical employees in techniques, methods, and interaction with impaired pupils and trainees: trainings, problem seminars, team work, business games, project technologies both in offline mode and using remote technologies [14].

These practice oriented formats allow not only to acquire knowledge in the field of inclusive education but to form special skills and habits, as well as ability to apply them in any new situation, which is the competence [15].

\section{Conclusion}

Therefore, the obtained results have allowed to determine the key problems of personnel provision of educational entities with experts skilled in teaching children with LHC; in addition, on the basis of analysis of experience of training experts for special defectologic education, the most efficient practice oriented interactive formats have been detected to improve inclusive competence of managerial and pedagogical teams of schools and colleges. 


\section{References}

1. O. Prikhodko, V. Manuylova, A. Huseynova, O. Yugova, SHS Web of Conferences, 70, 10007 (2019). https://doi.org/10.1051/shsconf/20197010007

2. I.Yu. Levchenko, A.Ya. Abkovich, Standards and Monitoring in Education, 3(4), 14 27 (2015). https://doi.org/10.12737/12925

3. T.G. Bogdanova, N.M. Nazarova, Pedagogika inklyuzivnogo obrazovaniya [Pedagogy of inclusive education] (Infra-M, Moscow, 2016)

4. O.G. Prikhodko, Deyatel'nost' spetsialistov soprovozhdeniya pri vklyuchenii obuchayushchikhsya s ogranichennymi vozmozhnostyami zdorov'ya i detey- invalidov v obrazovatel'noye prostranstvo [Activities of support specialists in the inclusion of students with disabilities and children with disabilities in the educational space] (Moscow State Pedagogical University, Moscow, 2014)

5. I.M. Yakovleva, Nachalnaya shkola, 7, 61-64 (2019)

6. K. Zierer, Oxford Review of Education, 41(6), 782-798 (2015). https://doi.org/10.1080/03054985.2015.1121140

7. P. Grossman, C. Pupik Dean, S.S. Kavanagh, Z. Herrmann, Phi Delta Kappan, 100(7), 43-48 (2019)

8. Ye.A. Yekzhanova, Ye.V. Reznikova, Spetsialnoye obrazovaniye, 4(52), 21-40 (2018)

9. E.I. Leonhard, Ye.G. Samsonova, Ye.A. Ivanova, Normalizatsiya usloviy vospitaniya i obucheniya detey s ogranichennymi vozmozhnostyami v usloviyakh inklyuzivnogo obrazovaniya [Normalization of the conditions for the upbringing and education of children with disabilities in the context of inclusive education] (Moscow State University of Psychology and Education, Moscow, 2018)

10. M.V. Zhigoreva, I.Yu. Levchenko, Vospitaniye i obucheniye detey s narusheniyami razvitiya, 4, 23-28 (2018)

11. I.Yu. Levchenko, O.G. Prikhodko, V.V. Manuylova, A.A. Guseynova, L.F. Holodnova, Standards and Monitoring in Education, 5(6), 34-40 (2017)

12. M. Lampert, F. Graziani, The Elementary School Journal, 109(5), 491-509 (2009) https://doi.org/10.1086/596998

13. L.Yu. Vakorina, O.G. Prikhodko, O.V. Yugova, Bulletin of the Peoples' Friendship University of Russia. Series: Sociology, 19(4), 814-824 (2019) https://doi.org/10.22363/2313-2272-2019-19-4-814-824

14. V.V. Manuylova, Special education, 1(41), 85-93 (2016)

15. N.M. Nazarova, Perspectives of Science and Education, 2(44), 354-365 (2020) 